\title{
the Prevailing 2013 Curriculum in Junior High School Practice: TEACHER PERSPECTIVE
}

\author{
Bunyamin $^{1)}$, Khoerul Umam ${ }^{2)}$ \\ 1) Universitas Muhammadiyah Prof. DR. HAMKA, Jakarta, Indonesia \\ E-mail: bunyamin@uhamka.ac.id \\ 2) Universitas Muhammadiyah Prof. DR. HAMKA, Jakarta, Indonesia \\ E-mail:khoerul.umam@uhamka.ac.id
}

\begin{abstract}
The 2013 Curriculum has been implemented in various schools in Jakarta. Although, the concept has been debated among teachers, and practitioners, some private and public schools in Jakarta have fully implemented this curriculum. The main purpose of this study was to examine teachers understanding of the prevailing 2013 Curriculum. This study used mix methods. The quantitative method was used to examine the teachers' competence about the 2013 Curriculum, while the qualitative method was used to strengthen and explore teachers' responses about curriculum in classroom practices. There were three different aspects that evaluated such as training period, classroom practice, and students' classroom engagement. The participant included 125 junior high school teachers from different parts of Jakarta. Data were collected through an online survey with a Likert scale. Data were analyzed by descriptive statistics. The result of this study reported that teachers have enough time to get their training but they need extra time to prepare for classroom practice. Students who be engaged the 2013 Curriculum in classroom practice have been supported to work collaboratively with their peers. Teachers need to be prepared such as equipment, classroom plan, book for the teacher, and time for meeting among their peer teaching. In the class practice, teachers need allotted time to prepare for teaching and examination.
\end{abstract}

Keywords: The 2013 Curriculum; Classroom Practice; Teachers perspective

\section{INTRODUCTION}

Curriculum was a fundamental aspect of classroom learning activity that teachers use for teaching practice. Teacher perform an important role in the implementation of curriculum in classroom practice (Albadi, Harkins, \& O'Toole, 2018; Eren, 2018). Classroom learning nowadays oriented not only to learning outcomes but also others achievements skills such as creativity, and critical thinking(Tan, 2018; Umam, 2011; Umam, Suswandari, Asiah, \& Rohim, 2017). In everyday class meeting, teachers meet different students with different various of cultural background and habits (Karunia, Amin, \& Chiar, 2018). For example, students in Junior high school Jakarta was not dominated by one race because most of students has cultural background from different part of Indonesia. To prepare teachers competence, several formal educations has been prepared (Utami, Wahyudi, \& Fadillah, 2018).
The minimum education is bachelor degree. Furthermore, teachers were invited to follow the trainings. To implement the 2013 Curriculum, several trainings have been conducted in school level, teachers group discussion, and many others level. Producing valid and reliable professional standard for teacher to improve teaching and teachers' competences quality has been inevitable issue (Eren, 2018). Teacher need to have good communication skills, and the principle competence according to their subjects. Training give teachers the theoretical background on curriculum, and give an opportunity for teacher to improve gradually their teaching quality. The period of time in curriculum training was diverse. The purpose of teacher training was to established teachings' comprehensive knowledge-based to accomplish their previous competences (Albadi, Harkins, \& Toole, 2019).

Based on the local government report, most of Junior High School teachers in Jakarta has implemented the 2013 
Curriculum in classroom practice. Although, in 2017, the government has recommended the postponed curriculum practice in school. The main reasons were teachers understanding about curriculum practice was merely low. The debate among teachers about this recommendation was inevitable. To get the comprehensive evaluation for teachers' understanding related to the 2013 Curriculum, we need to examine whether teachers understanding about curriculum, the survey should be conducted. The evaluation for this implementation is highly required. The main purpose of this research was to examine teachers understanding of the prevailing 2013 Curriculum. There are three different aspects that will be evaluated such as training period, classroom practice, and students' classroom engagement.

\section{MethodOLOGY}

The main purpose of this research was to examine the prevailing 2013 Curriculum in classroom practice. To achieve the main purposes, this study used mix methods. First, the quantitative method was used to examine the teachers' competence in the 2013 Curriculum, while the qualitative method was used to strengthen and explore teachers' responses about curriculum in classroom practices.

The research instrument was made included three different aspects that evaluated such as training period, classroom practice, and students' classroom engagement. The instrument had been validated by experts and reliability had been tested before data collection.

To collect the data, the first, the instrument was written into an online survey form. After preparing data, the invitation was written to ask the participants to fill the survey using a Likert scale. The survey was distributed in social media applications such as WhatsApps, Instagram, and Facebook.

The participant of this research was restricted for teachers in Jakarta province who has different teaching experiences and cultural background. All participants were invited to join the online survey. The demographics of participants are presented in Table I. The participants needed to fill the survey for approximately about 15 minutes. At the end of the survey, teachers had been asked to write their comments minimum a hundred words about the prevailing curriculum.

\section{RESULTS AND DISCUSSION}

In this section, teachers' responses about three different aspects of training the 2013 Curriculum had been presented, challenges of the 2013 Curriculum in classroom practice, and students' learning motivation with the 2013 Curriculum.

\section{A. Training the 2013 Curriculum}

Table II provides a summary of the teachers' responses about the existing training of the 2013 Curriculum. In general, teachers agreed that they have followed several workshops for implementation of the 2013 Curriculum $($ Mean $(M)=4.13$, Standard Deviation $(S D)=1.13)$. The workshop was organized by the educational department in various places. Result of teachers'self-assessment tended to believe that most the teachers have understood the implementation of the 2013 Curriculum $(\mathrm{M}=4.32$, SD $=$ 1.01).

TABLE I

PARTICIPANT DEMOGRAPHIC DATA (N=125)

\begin{tabular}{|c|c|c|c|c|}
\hline Teaching at Grade & Teachings' Experience & School Type & Race & Gender \\
\hline \multirow[t]{5}{*}{ Grade $7^{\text {th }}$} & $1^{\text {st }}$ year: $4(11 \%)$ & Private & Sundanese: $25 \%$ & Female: $22(61 \%)$ \\
\hline & & School* & Jakarta: $11 \%$ & \\
\hline & $<5^{\text {th }}$ years: $23(64 \%)$ & & Sumatra: $19 \%$ & Male:14(39\%) \\
\hline & & & Javaness:36\% & \\
\hline & $>5^{\text {th }}$ years: $9(25 \%)$ & & Out of java and Sumatra: $8 \%$ & \\
\hline \multirow[t]{5}{*}{ Grade $7^{\text {th }}$} & $1^{\text {st }}$ year: $2(6 \%)$ & Public & Sundanese: $27 \%$ & Female: $19(59 \%)$ \\
\hline & & School & Jakarta:23\% & \\
\hline & $<5^{\text {th }}$ years: $5(14 \%)$ & & Sumatra: $7 \%$ & Male:11 (31\%) \\
\hline & & & Javaness: $40 \%$ & \\
\hline & $>5^{\text {th }}$ years: $23(64 \%)$ & & Out of java and Sumatra: $3 \%$ & \\
\hline \multirow[t]{5}{*}{ Grade $8^{\text {th }}$} & $1^{\text {st }}$ year: $1(3 \%)$ & Private & Sundanese: $32 \%$ & Female: $19(61 \%)$ \\
\hline & & School* & Jakarta:26\% & \\
\hline & $<5^{\text {th }}$ years: $24(67 \%)$ & & Sumatra: $6 \%$ & Male:12(39\%) \\
\hline & & & Javaness: $29 \%$ & \\
\hline & $>5^{\text {th }}$ years: $6(17 \%)$ & & Out of java and Sumatra: $6 \%$ & \\
\hline \multirow[t]{5}{*}{ Grade $8^{\text {th }}$} & $1^{\text {st }}$ year: $2(6 \%)$ & Public & Sundanese: $29 \%$ & Female: $18(64 \%)$ \\
\hline & & School & Jakarta:11\% & \\
\hline & $<5^{\text {th }}$ years: $8(22 \%)$ & & Sumatra: $11 \%$ & Male:10 (36\%) \\
\hline & & & Javaness: $46 \%$ & \\
\hline & $>5^{\text {th }}$ years: $18(50 \%)$ & & Out of java and Sumatra: $4 \%$ & \\
\hline
\end{tabular}

*Private school excluded an international junior high school. 
TABLE II

TEACHERS RESPONSES ABOUT TRAINING THE 2013 CURRICULUM

\begin{tabular}{|c|c|c|c|}
\hline $\begin{array}{l}\text { F1: } \\
\text { Cur }\end{array}$ & $\begin{array}{l}\text { Aspects of training the } 2013 \\
\text { iculum }\end{array}$ & $\mathbf{M}$ & SD \\
\hline Q1 & $\begin{array}{l}\text { I have followed several workshops for } \\
\text { implementation of Curriculum } 2013\end{array}$ & 4.13 & 1.31 \\
\hline Q2 & $\begin{array}{l}\text { I have understood the implementation } \\
\text { of the } 2013 \text { Curriculum }\end{array}$ & 4.32 & 1.01 \\
\hline Q3 & $\begin{array}{l}\text { School has facilitated teachers to get } \\
\text { special training }\end{array}$ & 4.18 & 1.48 \\
\hline Q4 & $\begin{array}{l}\text { I get regular training for the } 2013 \\
\text { Curriculum every six months }\end{array}$ & 3.56 & 0.90 \\
\hline Q5 & $\begin{array}{l}\text { I initiated to join the training of the } \\
2013 \text { Curriculum organized by trainers }\end{array}$ & 2.96 & 1.11 \\
\hline Q6 & $\begin{array}{l}\text { I examine my understanding of the } \\
2013 \text { Curriculum through reading book }\end{array}$ & 2.91 & 1.05 \\
\hline Ave & age Score F1 & 3.67 & 1.14 \\
\hline
\end{tabular}

Most of teachers had answered that their school has facilitated teachers to join special training for the 2013 Curriculum $(\mathrm{M}=4.18, \mathrm{SD}=1.48)$. The school principal had assigned them to join the workshop either organized by government or private sectors. Furthermore, the questionnaire results showed that teachers get regular training for the 2013 Curriculum every six months $(\mathrm{M}=$ $3.56, \mathrm{SD}=0.90)$. This result in line with the report by Albadi et al., (2019) that teachers' regular training was gradually improve their pedagogical competence. On the other hand, teachers' interest to take special training the 2013 Curriculum was merely low $(\mathrm{M}=2.96, \mathrm{SD}=1.11)$. This is mainly because the training do not contribute to improve their prosperity. In line with Huincahue, Borromeo-Ferri, \& Mena-Lorca (2018) reported that improving teaching quality should be appropriate to improve the refinement of teachers welfare.

However, most of teachers were rarely get their understanding through reading book. Result reported that most of teachers do not agree that they understand the 2013 Curriculum through reading book $(\mathrm{M}=3.67, \mathrm{SD}=1.14)$. This result indicated that teachers are not interested in reading curriculum books.

To explore their reasons, some group representatives were also asked to comment on the statements. One teacher commented that teachers actually was very curious about the 2013 Curriculum, however, we do not have enough time to improve our competence. This is mainly because we do not only have to prepare the teaching lesson but also, we give daily assessment on student's achievement and behaviour (Ainley \& Ainley, 2011; Kuks, 2010).

\section{B. Challenges of the 2013 Curriculum in Classroom Practice}

Table III provides a summary of the teachers' responses about Challenges of the 2013 Curriculum in Classroom Practice. In general, there are numbers of challenging in implementing this curriculum. Most of teachers agreed that curriculum 2013 need special preparation like teaching and examination $(\mathrm{M}=4.13, \mathrm{SD}=1.31)$. To strength the quantitative results, the interviewed had been provided. Teachers commented that teaching preparation need an extra time and power as well. This is mainly because most of teachers' obligation were adequately many such as making teaching planning, providing students daily assessment, preparing next meeting, and assist school administration as well. If teachers obligations do not distribute accurately, then the quality of classroom learning is gradually low (Lloyd, Truong, \& Gray, 2018).

TABLE III

Challenges of THE 2013 CURRICULUM In ClassRoOM PRACTICE

\begin{tabular}{|c|c|c|c|}
\hline \multicolumn{2}{|c|}{$\begin{array}{l}\text { F2: Challenges of the } 2013 \text { Curriculum in } \\
\text { Classroom Practice }\end{array}$} & M & SD \\
\hline Q1 & $\begin{array}{l}\text { I found the } 2013 \text { Curriculum need } \\
\text { special preparation like teaching and } \\
\text { examination }\end{array}$ & 4.13 & 1.31 \\
\hline Q2 & $\begin{array}{l}\text { Teachers need extra time for } \\
\text { classroom practices }\end{array}$ & 4.39 & 1.01 \\
\hline Q3 & $\begin{array}{l}\text { It is difficult to organize classroom } \\
\text { practice in small group discussions. }\end{array}$ & 4.92 & 0.38 \\
\hline Q4 & $\begin{array}{l}\text { I had conducted a regularly discuss in } \\
\text { a small group to handle the numbers of } \\
\text { curriculum challenging in classroom } \\
\text { practices. }\end{array}$ & 3.56 & 0.90 \\
\hline Q5 & $\begin{array}{l}\text { I am totally agreed that the } 2013 \\
\text { Curriculum is suitable for students in } \\
\text { junior high school }\end{array}$ & 3.59 & 0.95 \\
\hline
\end{tabular}

Average F2

4.120 .91

The 2013 Curriculum had suggested that students are encouraged to be active learner in the classroom. To explore this, we asked does teachers need extra time for classroom practices. Most of teachers said that teachers need extra time for classroom practices $(\mathrm{M}=4.39, \mathrm{SD}=$ 1.01). Furthermore, the questionnaire results showed that most of teachers do not agreed the difficult to organize classroom practice in small group discussion $(\mathrm{M}=4.92$, $\mathrm{SD}=0.38)$.

The result reported that most of the teachers were highly appreciated that the 2013 Curriculum is suitable for students in junior high school about the 2013 Curriculum $(\mathrm{M}=3.56, \mathrm{SD}=0.90)$. They insist on learning through discussion is highly recommended for students. This is mainly because most of the students' junior high school feel comfortable to learn with their peers (le Roux \& Nagel, 2018; Song, Boo, \& Nie, 2018). Although, some students were preferred to ask directly to teachers.

\section{Students' Learning Motivation with the 2013 Curriculum}

Table IV provides a summary of the students' learning motivation with the 2013 Curriculum. In general, teachers agreed that students are motivated in learning $(\mathrm{M}=4.08$, $\mathrm{SD}=1.11)$. This value indicated that students enjoy in classroom practice with the prevailing curriculum. 
Although, the result has reported that some students enjoy in small group learning model $(\mathrm{M}=3.78, \mathrm{SD}=0.94)$. Learning in small group discussion encourage smart students to dominate the discussion. Surprisingly, teachers reported that the 2013 Curriculum has encourage students to prepared the lesson before class $(\mathrm{M}=4.18, \mathrm{SD}=1.52)$. Although, it is difficult to encourage student to learn out of class. The given learning materials before class has gradually improve students interest to learn the subject earlier (le Roux \& Nagel, 2018; Long, Cummins, \& Waugh, 2017).

TABLE IV

STUDENTS' LEARNING MOTIVATION WITH THE 2013 CURRICULUM

\begin{tabular}{|c|c|c|c|}
\hline \multicolumn{2}{|c|}{$\begin{array}{l}\text { F3: Students' learning motivation with the } \\
2013 \text { Curriculum }\end{array}$} & \multirow{2}{*}{$\begin{array}{l}\mathbf{M} \\
3.78\end{array}$} & \multirow{2}{*}{$\begin{array}{l}\text { SD } \\
0.94\end{array}$} \\
\hline Q1 & $\begin{array}{l}\text { I found my students were motivated in } \\
\text { learning }\end{array}$ & & \\
\hline Q2 & $\begin{array}{l}\text { Some students were enjoyed in a small } \\
\text { group learning model }\end{array}$ & 4.18 & 1.52 \\
\hline Q3 & $\begin{array}{l}\text { Students have prepared the lesson before } \\
\text { class }\end{array}$ & 4.12 & 1.12 \\
\hline Q4 & $\begin{array}{l}\text { It is difficult to ask the students to learn } \\
\text { in their homes. }\end{array}$ & 4.01 & 1.15 \\
\hline Q5 & $\begin{array}{l}\text { Students were preferred to traditional } \\
\text { learning to the prevailing curriculum } \\
\text { practice. }\end{array}$ & 4.18 & 0.97 \\
\hline Q6 & $\begin{array}{l}\text { Students tend to view that school is the } \\
\text { only place to learn. }\end{array}$ & 4.20 & 0.96 \\
\hline \multicolumn{2}{|c|}{ Average F3 } & 4.08 & 1.11 \\
\hline
\end{tabular}

In general, teachers agreed that it is difficult to ask the students to learn in their home $(\mathrm{M}=4.01, \mathrm{SD}=1.15)$, that students were preferred to traditional learning to the prevailing curriculum practice. $(\mathrm{M}=4.18, \mathrm{SD}=0.97)$. Research by Bergmann \& Sams (2012) reported that teachers should prepare clear instruction to encourage students to learn individually in their home.

\section{CONCLUSIONS}

The result of this study reported that the teachers have enough time to get their training but they need extra time to prepare for classroom practice. Students who be engaged the 2013 Curriculum in classroom practice have been supported to work collaboratively with their peers. Teachers need to be prepared such as equipment, classroom plan, book for teacher, and time for meeting among their peer teaching. In the class practice, teachers need allotted time to prepare for teaching and examination.

\section{REFERENCES}

Ainley, M., \& Ainley, J. (2011). Student engagement with science in early adolescence: The contribution of enjoyment to students' continuing interest in learning about science. Contemporary Educational Psychology, 36(1), 4-12. https://doi.org/10.1016/j.cedpsych.2010.08.001
Albadi, N. M., Harkins, J., \& O’Toole, J. M. (2018). Recent Reforms in Saudi Secondary Science Education: Teacher and Student Perceptions of Grade 10 Physics. International Journal of Science and Mathematics Education, 1-21. https://doi.org/10.1007/s10763-018-9881-3

Albadi, N. M., Harkins, J., \& Toole, J. M. O. (2019). Recent Reforms in Saudi Secondary Science Education: Teacher and Student Perceptions of Grade 10 Physics.

Bergmann, J., \& Sams, A. (2012). Flip Your Classroom Reach Every Student in Every Class Every Day. https://doi.org/10.1111/teth.12165

Eren, A. (2018). Pre-service teachers' beliefs about the teaching profession, curriculum orientations, and personal responsibility. Curriculum Perspectives, $38(1), 1-14$

Huincahue, J., Borromeo-Ferri, R., \& Mena-Lorca, J. (2018). Math modeling knowledge from reflection in math teachers initial training. Ensenanza De Las Ciencias, 36(1), https://doi.org/10.5565/rev/ensciencias.2277

Karunia, A. T., Amin, M. M., \& Chiar, M. (2018). Improving The Quality of Process Standard Based on School-Based Management, 3(2), 252-259.

Kuks, J. B. M. (2010). The bachelor-master structure ( twocycle curriculum ) according to the Bologna agreement: a Dutch experience. Tijdschrift Voor Medisch Onderwijs, 29(1), 16-21.

le Roux, I., \& Nagel, L. (2018). Seeking the best blend for deep learning in a flipped classroom - viewing student perceptions through the Community of Inquiry lens. International Journal of Educational Technology in Higher Education, 15(1). https://doi.org/10.1186/s41239-018-0098-x

Lloyd, A., Truong, S., \& Gray, T. (2018). Take the class outside! A call for place-based outdoor learning in the Australian primary school curriculum. Curriculum Perspectives, 38(2), 163-167. https://doi.org/10.1007/s41297-018-0050-1

Long, T., Cummins, J., \& Waugh, M. (2017). Use of the flipped classroom instructional model in higher education: instructors' perspectives. Journal of Computing in Higher Education, 29(2), 179-200. https://doi.org/10.1007/s12528-016-9119-8

Song, L., Boo, H., \& Nie, Y. (2018). Attitude Towards Persons with Intellectual Disability Scale: Further Development. Curr Psychol, 37, 760-768. https://doi.org/10.1007/s12144-017-9560-5

Tan, M. (2018). When Makerspaces Meet School: Negotiating Tensions Between Instruction and 
Construction. Journal of Science Education and Technology, 75-89. https://doi.org/10.1007/s10956018-9749-x

Umam, K. (2011). Perbedaan Hasil Belajar Matemtika Siswa dengan Metode Problem Posing dan Metode Ekspositori di SMPN 188 Jakarta Materi Teorema Pythagoras. In Prosiding Seminar Nasional Matematika dan Pendidikan Matematika 2011 (pp. 182-190).

Umam, K., Suswandari, S., Asiah, N., \& Rohim, S. (2017). The Effect of Think-Pair-Share Cooperative Learning Model Assisted With ICT on Mathematical Problem Solving Ability among Junior High School Students. In Proceedings of the 25th International Conference on Computers in Education (pp. 94-18).

Utami, E., Wahyudi, \& Fadillah. (2018). Management of kindergarten ( TK ) Parenting Program IN Mujahidin 2 ON EAST Pontianak District. Journal of Education, Teaching and Learning, 3(2), 273-281. 